\title{
Cervical cancer screening among female undergraduates and staff in the Niger delta region of Nigeria
}

\author{
Ibrahim Ayuba Isa ${ }^{1 *}$, Owoeye Olugbenga Ibukun Gani ${ }^{2}$, Kalada McFubara ${ }^{2}$ \\ ${ }^{1}$ Department of Obstetrics and Gynaecology, College of Health Sciences, Niger Delta University, Amassoma, Nigeria \\ ${ }^{2}$ Department of community medicine, College of Health Sciences, Niger Delta University, Amassoma, Nigeria \\ Email: daddayzee@yahoo.com
}

Received 22 October 2012; revised 24 November 2012; accepted 3 December 2012

\begin{abstract}
A significant decrease in the incidence of cervical cancer and mortality is expected when all eligible women have access to regular Screening tests. Factors that can influence participation rate include: acceptability, accessibility, screening interval, promotion of screening among others. This study is aimed at the assessment of the risk factors for cervical cancer, the knowledge and level of utilization of cervical cancer screening among female staff and female undergraduates of Niger Delta University. A standard questionnaire was used for data collection. The questions were made to capture the objectives of the study. 182 (50.6\%) were aware of cervical cancer screening, 22 $(12.1 \%)$ of the respondents have had at least one pap test in the past, the commonest reasons for uptake of screening were; When it is free or subsidized 6 $(27.3 \%)$, as part of a general screening program 6 (27.3\%), Doctor's request $4(18.2 \%)$ and self-conviction $4(18.2 \%)$. Many $98(41.4 \%)$ of the respondents, considered themselves healthy and did not see any reason to subject themselves to any form of cervical cancer screening. The reasons for uptake and non uptake of cervical cancer screening are statistically significant between the students and staff $\left(x^{2}=18.175\right.$, $\left.p=0.001 ; x^{2}=11.31, p=0.046\right)$. The mean age for the initiation of penetrative sex among the respondents was $15.4 \pm 2.7,226(71.1 \%)$ had more than one sexual partner and $184(51.0 \%)$ had been treated for sexually transmitted infections in the past. The study shows that awareness of cervical cancer screening and Uptake was low amongst the respondents, this is despite the fact that a large proportion of the respondents had risk factors for cervical cancer.
\end{abstract}

Keywords: Knowledge; Cervical Cancer; Risk Factors; Screening; Niger Delta

*Corresponding author.

\section{INTRODUCTION}

Cervical cancer is a malignant disease of the cervix usually occurring in the $5^{\text {th }}$ or $6^{\text {th }}$ decade of life at a mean age of 54 years. The disease has a pre-malignant stage which usually occurs in younger women under the age of 40. It is associated with the following risk factors; early age at first sexual intercourse, multiple male sexual partners, male sexual partners who themselves have had multiple partners, early age at first birth, multiparty, smoking, long-term use of oral contraceptive pills, immunosuppresed states [1].

Cancer of the cervix is a preventable disease and a key aspect of its prevention is the detection of the pre malignant form by cervical screening. It is also one type of cancer that can be prevented and cured if detected early enough [2]. The long transition time from a premalignant lesion to frank cancer of the cervix affords ample time for early detection and nearly complete cure even in secondary health care centres. However this window of opportunity which has enabled the developed countries to reduce the incidence of cancer of the cervix would be wasted if the level of screening is low [3]. The greatest burden of cervical cancer occurs in the developing world where the mortality rate ranges from 10 to 35 per 100,000 compared with 2 to 4 deaths per 100,000 in developed nations [4]. This difference is attributed to effective national screening programs of cervical cytologic testing (the Papanicolaou test) to identify cell abnormalities that may indicate or precede cervical cancer [5, $6]$.

It is worthy of note that it takes about 10 years for precancerous lesions of the cervix to progress to cervical cancer. Ideally a woman is supposed to get regular Pap smear; as such the ideal age for screening is expected to be at $30-40$ years which is the age range of which women are at highest risk. However younger women who have been sexually active should be screened as they might have pre malignant lesions and even cervical cancer especially if they have HIV infection. It is sufficient to know that cervical cancer screening has posi- 
tive association with certain strains of Human Papilloma Virus (HPV) and repeated or persistent HPV infections appear to raise the chances of developing the disease. The good news is that HPV vaccines are now available, which gives new promise for a primary prevention strategy of HPV infection and cancer, however the vaccines only protect against $70 \%$ of the disease and are only effective on those who have not been exposed to HPV virus. Various screening techniques have been developed and among those employed are: Pap smear test, visual inspection with acetic acid (VIA) and HPV DNA test [7-10].

The delivery of cervical cancer screening in Nigeria is usually conducted in an opportunistic manner, whereby screening depends on the initiative of the woman and/or her health care provider. This may lead to inappropriate screening utilization and inadequate follow-up of abnormal results. There is currently no mass screening program for the detection of cervical cancer in Nigeria. Services are only available in teaching hospitals and are not adequately utilized. Constraints against underutilization were found to be poverty, ignorance and system failure [11].

Women's undergoing cervical cancer screening suggests that they are aware that they should be screened; however they may lack basic understanding of the process, limitation and results of the Pap test. The more knowledgeable women are about Pap testing, the more likely they are to make a screening visit and to adhere to recommended follow-up for an abnormal result [12,13].

The current wisdom about cervical cancer control is the critical importance of early detection. However most of the women in developing nations present with advanced disease when nothing can be done for them [14]. everal reasons for the late presentations have been noted namely; ignorance about the symptoms, fatalistic attitude (i.e. fear of death from the disease), readiness to attribute neoplastic disease to supernatural causes thereby resulting in delays in seeking help, fear of confirmation of suspicion and of course the perennial problem of low coverage of the population by health centre services especially the rural areas $[15,16]$. Furthermore, it has been reported that $50 \%$ - $90 \%$ of women who develop or die from cervical cancer have never been screened [17]. A literature search identified studies that examine factors influencing women's participation in screening program, their psychological reaction to the receipt of an abnormal cervical smear result, and experiences of colposcopy. Reasons given for nonparticipation included administrative failures, inconvenient clinic times, unavailability of a female screener, lack of awareness of the test's indications and benefits, considering one-self not to be at risk of developing cervical cancer, and fear of embarrassment, pain, or the detection of cancer. The receipt of an abnormal result and referral for colposcopy cause high levels of distress owing to limited understanding of the meaning of the smear test, many women believe the test aims to detect existing cervical cancer [18].

Cervical cancer screening is relatively inexpensive and there is worldwide agreement that screening programmes for cervical cancer are a necessity [11]. A significant decrease in the incidence of cervical cancer and mortality is expected when all eligible women have access to regular screening, Factors that can influence participation rate include: acceptability, accessibility, screening interval, promotion of screening among others [19]. Cervical cancer screening services are not readily available in the state at present. It is therefore expected that the findings and recommendations of this study would provide guidelines for the provision and utilization of cervical cancer screening in our environment, and thereby contribute to the reduction of the incidence and mortality of cervical cancer.

\section{METHODOLOGY}

The Niger Delta University has 10,683 students with a female to male ratio of 1:1.7 respectively. There about 3578 academic and non-academic staff in the university, with 636 male and 135 female academic staff, 394 male and 188 female senior non-academic staff, and 852 male and 1348 female junior non-academic staff. The study population comprised female staff and students of the University within the age range of 16 - 65 years.

This is a descriptive cross-sectional study. A 26-item self-administered questionnaire was designed to assess the sexual risk factors for cervical cancer, the knowledge and level of utilization of cervical cancer screening among female staff and female undergraduates of Niger Delta University based upon similar studies conducted elsewhere and literature review. The questionnaire was used to obtained information on the socio-demographic characteristics of the respondents, risk factors, Knowledge and uptake of cervical cancer screening, The questionnaires were administered by the researchers to a total of 400 participants. Respondents were given a free hand in response to questions and were only guided in their responses when they voluntarily called for assistance. They were also assured that the information provided would be kept confidential.

Multistage sampling was used for the recruitment of study participants into both study groups. Stage one; involved stratification of females of Niger Delta University into two categories: staff and students. Stage two involved determination of proportional allocation into staff and students using a sample frame obtained from the University. Stage three involved simple random 
sampling for the selection of target student population. Four faculties were selected from the twelve faculties in the University, which includes Faculties of Law, Nursing, Pharmacy and social Sciences. the self-administered questionnaire was administered by quota purposive sampling method to members of a faculty irrespective of year or department of study. The information obtained were coded and transferred onto a profoma already design for the study. Statistical analysis was performed with Statistical Package for Social Sciences software SPSS version 11 where nominal data were compared using the chi square test $\left(\mathrm{x}^{2}\right)$ and the difference between means determined by the students t-test with the level of significance set at $\alpha=0.05$. Approval for this work was obtained from the Ethical Committee of the Niger Delta University.

\section{RESULTS}

A total of 360 questionnaires were analyzed; 100 from staff and 260 from the students. Of the remaining 40 questionnaires, 32 were not returned while 8 were filled incorrectly. Table 1 shows the socio-demographic distribution of respondents. The age range of respondents was $16-45$ (mean $=23.65 \pm 5$ years) for students and 16 - 65 for staff (mean $=38.8 \pm 9.05$ years). Most of the respondents were Christians and of Ijaw tribe. Majority of the staff were married $\left(x^{2}=97.5, p=0.00\right)$. Table 2 shows the awareness of cervical Screening and sexual profile. The mean age for the initiation of penetrative sex among the respondents was $15.4 \pm 2.7,193$ (53.7\%) of the respondents had their sexual debut (coitarche) before the age of 20 years while 226 (71.1\%) had more than one sexual partner, and 184 (51.0\%) had been treated for sexually transmitted infections in the past. Awareness of cervical cancer screening was higher amongst the students than staff, (56.2\% versus 36\%) there was however no significant difference in the level of awareness $\left(\mathrm{x}^{2}=\right.$ 11.73, $\mathrm{p}=0.001)$.

Both students and staff differed significantly in the reasons for being screened $\left(\mathrm{x}^{2}=18.175, \mathrm{p}=0.001\right)$, there is also a significant association in the reasons for not being screened $\left(x^{2}=11.31, p=0.046\right)$ (Table 3$)$.

\section{DISCUSSION}

Awareness of cervical cancer screening was higher

Table 1. Socio-demographic distribution of respondents.

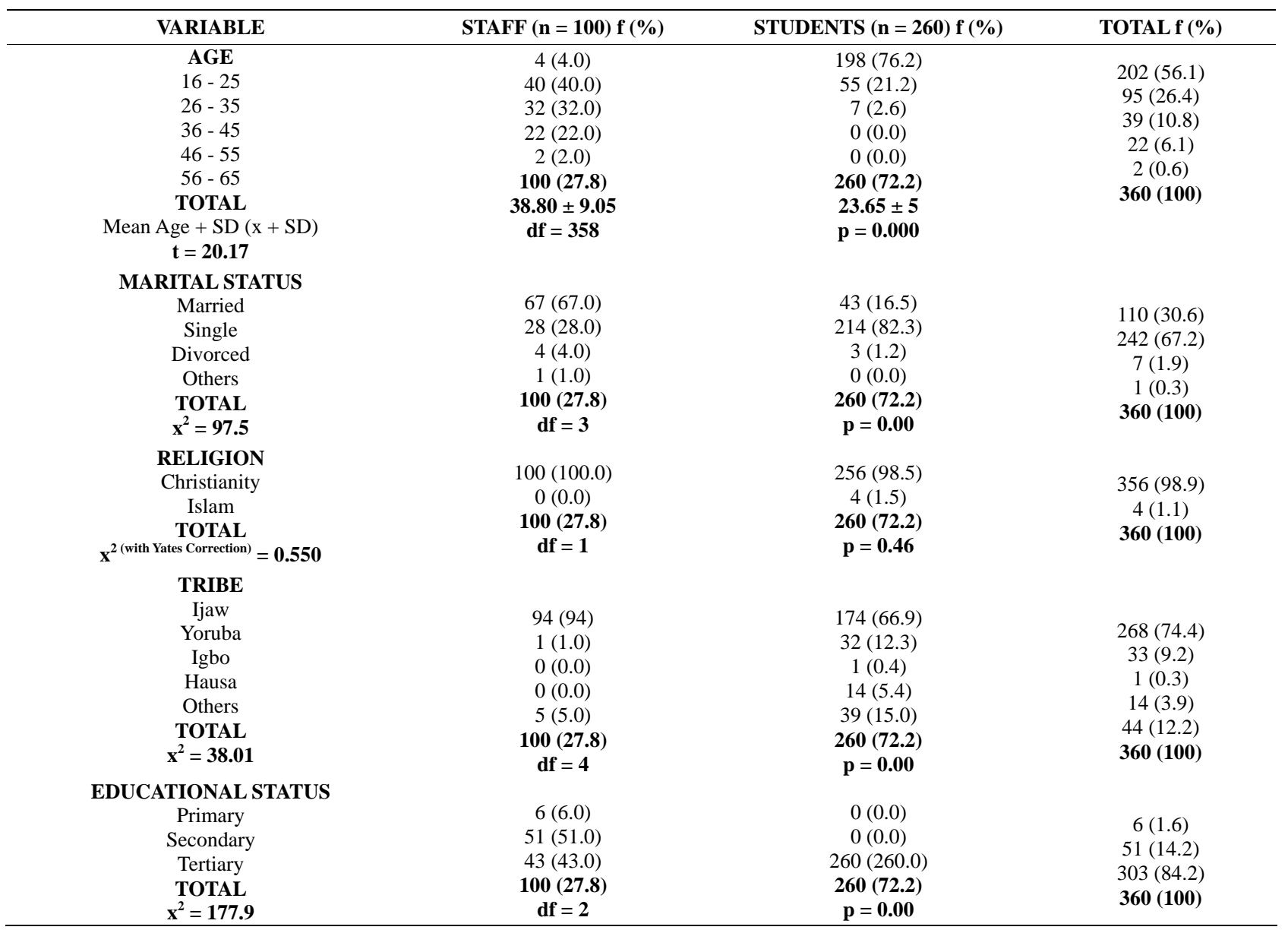


amongst the students than staff, (56.2\% versus 36\%) there was however no significant difference in the level of awareness. This could be due to the fact that about half the students were Health Sciences students and would have known about cervical cancer and cervical cancer screening in the cause of their study. Also, all the students had tertiary level of education. The low level of knowledge is similar to findings in developing countries [20,21].

There was no significant difference in the level of uptake amongst respondents. Uptake was generally low (13\% staffs and $11.6 \%$ students). This might be due to the fact that there is no established general screening programme within the university and even the state. Similar findings of low uptake have been recorded in other developing countries including Nigeria [22-24].

In a study carried out in Ghana, the uptake was $8.5 \%$ while it was $5.7 \%$ and $8.7 \%$ in Nnewi and Ogun state in Nigeria respectively [22-25]. The low participation in cervical cancer screening observed in this study and similar studies in developing countries is unlike the findings in most developed countries with market economy and computerized screening programmes where uptake of cervical cancer screening was generally high. In one of such studies in Germany, most women in the study group had a Pap smear test at least once a year and only a few had a smear less frequently than every five years. Also among Chinese American women in the United states, uptake of Pap smear was as high as $84 \%$ $[26,27]$.
However, both students and staff differed significantly in the reasons for being screened. Majority of the staff

Table 2. Awareness of cervical screening \& sexual profile.

\begin{tabular}{|c|c|c|c|}
\hline VARIABLE & $\begin{array}{c}\text { STAFF } \\
(\mathbf{n}=100) \\
\mathbf{f}(\%)\end{array}$ & $\begin{array}{c}\text { STUDENTS } \\
(\mathbf{n}=260) \\
\mathbf{f}(\%)\end{array}$ & $\begin{array}{c}\text { TOTAL } \\
\text { f (\%) }\end{array}$ \\
\hline $\begin{array}{c}\text { HEARD OF } \\
\text { CERVICAL } \\
\text { CANCER } \\
\text { SCREENING } \\
\text { Yes } \\
\text { No } \\
\text { TOTAL } \\
\mathbf{x}^{2}=11.73\end{array}$ & $\begin{array}{c}36(36.0) \\
64(64.0) \\
\mathbf{1 0 0}(\mathbf{2 7 . 8 )} \\
\mathrm{df}=1\end{array}$ & $\begin{array}{l}146(56.2) \\
114(43.8) \\
\mathbf{2 6 0}(\mathbf{7 2 . 2 )} \\
\mathbf{p}=\mathbf{0 . 0 0 1}\end{array}$ & $\begin{array}{l}182(50.6) \\
178(49.4) \\
\mathbf{3 6 0}(\mathbf{1 0 0 )}\end{array}$ \\
\hline $\begin{array}{c}\text { ENGAGED IN } \\
\text { PENETRATIVE } \\
\text { SEX } \\
\text { YES } \\
\text { NO } \\
\mathbf{x}^{2}=1.81\end{array}$ & $\begin{array}{c}92(92.0) \\
8(8.0) \\
\mathbf{d f}=\mathbf{1}\end{array}$ & $\begin{array}{c}226(86.9) \\
34(13.1) \\
\mathbf{p}=\mathbf{0 . 1 7 9}\end{array}$ & $\begin{array}{c}318(88.3) \\
42(11.7)\end{array}$ \\
\hline $\begin{array}{c}\text { PREVIOUS } \\
\text { SEXUAL } \\
\text { PARTNERS } \\
1 \\
2-3 \\
4-5 \\
>5 \\
x^{2}=11.1\end{array}$ & $\begin{array}{c}17(18.5) \\
39(42.4) \\
24(26.1) \\
12(13.0) \\
\mathbf{d f}=3\end{array}$ & $\begin{array}{l}75(33.2) \\
83(36.7) \\
32(14.2) \\
36(15.9) \\
\mathbf{p}=\mathbf{0 . 0 1 1}\end{array}$ & $\begin{array}{c}92(28.9) \\
122(38.4) \\
56(17.6) \\
48(15.1)\end{array}$ \\
\hline $\begin{array}{c}\text { PREVIOUS } \\
\text { TREATMENT FOR } \\
\text { STI } \\
\text { YES } \\
\text { NO } \\
\mathrm{x}^{2}=3.65\end{array}$ & $\begin{array}{c}43(43.0) \\
57(57.0) \\
\mathbf{d f}=\mathbf{1}\end{array}$ & $\begin{array}{l}141(54.2) \\
119(45.8) \\
\mathbf{p}=\mathbf{0 . 0 5 6}\end{array}$ & $\begin{array}{l}184(51.0) \\
176(49.0)\end{array}$ \\
\hline
\end{tabular}

Table 3. Uptake of cervical cancer screening by respondents.

\begin{tabular}{|c|c|c|c|}
\hline VARIABLE & STAFF $(n=100) f(\%)$ & STUDENTS $(n=260)$ f $(\%)$ & TOTALf (\%) \\
\hline \multicolumn{4}{|l|}{ HAD CERVICAL CANCER SCREENING } \\
\hline Yes & $5(13.9)$ & $17(11.6)$ & \\
\hline No & $31(86.1)$ & $129(88.4)$ & $22(12.1)$ \\
\hline TOTAL & $36(19.8)$ & $146(80.2)$ & $160(87.9)$ \\
\hline$x^{2}=0.137$ & $\mathbf{d f}=1$ & $p=0.711$ & \\
\hline \multicolumn{4}{|c|}{$\begin{array}{l}\text { Reasons for uptake of cervical screening test } \\
\text { (Those who showed awareness \& had screening) }\end{array}$} \\
\hline Doctor's request & 0 & $4(23.5)$ & \\
\hline Free/Subsidized & 0 & $6(35.3)$ & $4(18.2)$ \\
\hline Self-conviction & $4(80.0)$ & $0(0.0)$ & $6(27.3)$ \\
\hline Part of a general screening Program & $1(20.0)$ & $5(29.4)$ & $4(18.2)$ \\
\hline No response & $0(0.0)$ & $2(11.8)$ & $6(27.3)$ \\
\hline TOTAL & $5(22.7)$ & $17(77.3)$ & $2(9.0)$ \\
\hline$x^{2}=18.175$ & df $=4$ & $\mathbf{p}=\mathbf{0 . 0 0 1}$ & $22(100)$ \\
\hline \multicolumn{4}{|c|}{$\begin{array}{l}\text { Reasons for non-uptake of cervical screening test } \\
\text { (Those who showed awareness \& did not have screening) }\end{array}$} \\
\hline It is Painful & $3(7.9)$ & $2(1.0)$ & \\
\hline It is Expensive & $1(2.6)$ & $19(9.6)$ & $5(2.1)$ \\
\hline It is Embarrassing & $0(0.0)$ & $10(5.0)$ & $20(8.4)$ \\
\hline I am Healthy & $18(47.4)$ & $80(40.2)$ & $10(4.2)$ \\
\hline Others & 7 (18.4) & 35 (17.6) & $98(41.4)$ \\
\hline No Response & 9 (23.7) & $53(26.6)$ & 42 (17.7) \\
\hline TOTAL & $38(16.0)$ & $199(84.0)$ & $62(26.2)$ \\
\hline$x^{2}=11.31$ & $\mathrm{df}=5$ & $\begin{array}{l}199(8.04) \\
p=0.046\end{array}$ & 237 (100) \\
\hline
\end{tabular}


who has participated in a screening test, $80 \%$ did so out $\mathrm{f}$ self conviction while screening test being free and subsidized was the main reason for uptake among students. This suggests that uptake of cervical cancer screening is likely to increase if the test is made free or subsidized.

Moreover, among respondents who have never done cervical cancer screening, there is an association in the reasons for not being screened between the respondents. Majority of the respondents gave being healthy as a reason for not being screened. This implies that they do not consider themselves at risk for the disease and as such do not see the need to be screened. However,the respondents have obvious risk factors for cervical cancer; 193 (53.7\%) of the respondents had their sexual debut (coitarche) before the age of 20 years, while 226 (71.1\%) had multiple sexual partners, this is much high than findings reported from another study in Nigeria [22]. Furthermore, most of the respondents had history of previous treatment for sexually transmitted infections. This does not pose a good picture for the effective control of this disease as studies in the Netherlands have shown that women considering they not being at risk is a reason for non-uptake and pulling out of screening programmes $[28,29]$. This is not unconnected with the low level of utilization of screening observed in this study.

In conclusion sexual risk factors for cervical cancer like early age of coitus, multiple sexual partners and previous treatment for sexually transmitted infections are high and awareness of cervical cancer screening was higher amongst students than staff of Niger Delta University. Uptake was low in both staff and students. A greater proportion of the staff respondents had little or no knowledge of cervical cancer screening.

There is a need for the authorities of tertiary educational institutions and particularly those of Niger Delta University to incorporate regular cervical Cancer screening into the health care of their staff and students, in addition to health education on the dangers of early sexual debut and multiple sexual partners.

\section{REFERENCES}

[1] Anorlu, R.I. (1997) Tumours of the cervix uteri. Textbook of Obstetrics and Gynaecology for Medical Students, 2, 167-182.

[2] Arevian, M., Noureddine, S. and Kabakian-Khasholian, T. (2006) Raising awareness and providing free screening improves cervical cancer screening among economically disadvantaged Lebanese/Armenian women. Journal of Transcultural Nursing, 17, 357-365. doi:10.1177/1043659606291542

[3] Hakama, M., Joutsenlahti, U., Virtaren, A., et al. (1975) Mass screening for cervical cancer in Finland 1963-1971. Organization, extent and epidemiological implications. Annals of Clinical Research, 7, 101-111.
[4] Arbyn, M., Castellsagué, X., de Sanjosé, S., Bruni, L., Saraiya, M., Bray, F. and Ferlay, J. (2011) Worldwide burden of cervical cancer in 2008. Annals of Oncology, 22, 2675-2686. doi:10.1093/annonc/mdr015

[5] Peto, J., Gilham, C., Fletcher, O. and Matthews. F.E. (2004) The cervical cancer epidemic that screening has prevented in the UK. Lancet, 364, 249-256. doi:10.1016/S0140-6736(04)16674-9

[6] Quinn, M., Babb, P., Jones, J. and Allen, E. (1999) Effect of screening on incidence of and mortality from cancer of cervix in England: Evaluation based on routinely collected statistics. British Medical Journal, 318, 904-908. doi:10.1136/bmj.318.7188.904

[7] Maggwa, B.N., Hunter, D.J., Mbugua, S., Tukei, P. and Mati, J.K. (1993) The relationship between HIV infection and cervical intraepithelial neoplasia among women attending two family planning clinics in Nairobi, Kenya. AIDS, 7, 733-738. doi:10.1097/00002030-199305000-00019

[8] Olamijulo, J. and Duncan, I.D. (1995) Is cervical cytology screening of teenagers worthwhile? British Journal of Obstetrics and Gynaecology, 102, 515-516. doi:10.1111/j.1471-0528.1995.tb11351.x

[9] Kapiga, S.H., Msamanga, G.I., Spiegelman, D., Mwakyoma, H., Fawzi, W.W. and Hunter, D.J. (1999) Risk factors for squamous intraepithelial lesions among HIV-1 seropositive women in Dares Salaam, Tanzania. International Journal of Gynecology \& Obstetrics, 67, 87-94. doi:10.1016/S0020-7292(99)00125-3

[10] Leroy, V., Ladner, J., DeClercq, A., Meheus, A., Nyiraziraje, M., Karita, E. and Dabis, F. (1999) Cervical dysplasia and HIV type 1 infection in African pregnant women: A cross sectional study, Kigali, Rwanda. The pregnancy and HIV Study Group (EGE). Sexually Transmitted Infections, 75, 103-106. doi:10.1136/sti.75.2.103

[11] Ngoma, T. (2006) World Health Organization cancer priorities in developing countries. Annals of Oncology, 17, viii9-viii14.

[12] Dignan, M., Michielutte, R., Blinson, K., Wells, H.B., Case, L.D., Sharp, P., et al. (1996) Effectiveness of health education to increase screening for cervical cancer among eastern-band Cherokee Indian women in North Carolina. Journal of the National Cancer Institute, 88, 1670-1676. doi:10.1093/jnci/88.22.1670

[13] Schofield, M.J., Sanson-Fisher, R., Halpin, S. and Redman, S. (1994) Notification and follow-up of Pap test results: Current practice and women's preferences. Preventive Medicine, 23, 276-283. doi:10.1006/pmed.1994.1039

[14] Ayinde, O.A., Omigbodun, A.O. and Ilesanmi, A.O. (2004) Awareness of cervical cancer, Papanicolaou's smear and it's utilisation among female undergraduates in Ibadan. African Journal of Reproductive Health, 8, 68-80. doi: $10.2307 / 3583394$

[15] Adewole, I.F., Benedet, J.L., Brian, T.C. and Follen, M. (2005) Evolving a strategic approach to cervical cancer control in Africa. Gynecologic Oncology, 99, 209-212.

[16] Olukoya, A.A. (1989) Cancer of the breast and cervix in 
Nigerian women and the role of primary health care. $\mathrm{Ni}$ gerian Medical Practitioner, 18, 26-30.

[17] Anonymous (1984) Cervical screening: Editorial. The British Journal of Family Planning, 10, 1-2.

[18] Fylan, F. (1998) Screening for cervical cancer: A review of women's attitudes, knowledge, and behavior. British Journal of General Practice, 48, 1509-1514.

[19] Lara, E., Day, N.E. and Hakama, M. (1987) Trends in mortality from cervical cancer in Nordic countries: Association which organized screening program. Lancet, 1, 1247-1249. doi:10.1016/S0140-6736(87)92695-X

[20] Claeys, P., Gonzalez, C., Gonzalez, M., Page, H., Bello, R.E. and Temmerman, M. (2002) Determinants of cervical cancer screening in a poor area: Results of a populationbased survey in Rivas, Nicaragua. Tropical Medicine and International Health, 7, 935-941. doi:10.1046/j.1365-3156.2002.00953.x

[21] McFarland, D.M. (2003) Cervical cancer and Pap smear screening in Botswana: Knowledge and perceptions. International Nursing Review, 50, 167-175.

[22] Gharoro, E.P. and Ikeanyi, E.N. (2006) An appraisal of the level of awareness and utilization of the Pap smear as a cervical cancer screening test among female health workers in a tertiary health institution. International Journal of Gynecological Cancer, 16, 1063-1068. doi:10.1111/j.1525-1438.2006.00579.x

[23] Udigwe, G.O. (2006) Knowledge, attitude and practice of cervical cancer screening (Pap smear) among female nurses in Nnewi, South Eastern Nigeria. Nigerian Journal of Clinical Practice, 9, 40-43.
[24] Adefuye, P.O. (2006) Knowledge and practice of cervical cancer screening among female professional health workers in a sub-urban district of Nigeria. Nigerian Medical Practitioner, 50, 19-22. doi:10.4314/nmp.v50i1.28829

[25] Adanu, R.M.K. (2002) Cervical cancer knowledge and screening in Accra, Ghana. Journal of Women's Health and Gender-Based Medicine, 11, 487. doi:10.1089/152460902760277822

[26] Klug, S.J., Hetzer, M. and Blettner, M. (2005) Screening for breast and cervical cancer in a large German city: Participation, motivation and knowledge of risk factors. European Journal of Public Health, 15, 70-77. doi:10.1093/eurpub/cki118

[27] Lee-Lin, F., Pett, M., Menon, U., Lee, S., Nail, L., Mooney, K. and Itano, J. (2007) Cervical cancer and Pap test screening practices among Chinese-American immigrants. Oncology Nursing Forum, 34, 1203-1209. doi:10.1188/07.ONF.1203-1209

[28] Tacken, M.A.J.B., Braspenning, J.C.C., Hermens, R.P.M.G., Spreeuwenberg, P.M.M., Van Den Hoogen, H.J.M., De Bakker, D.H., et al. (2007) Uptake of cervical cancer screening in the Netherlands is mainly influenced by women's beliefs about the screening and by the inviting organization. The European Journal of Public Health, 17, 178-185. doi:10.1093/eurpub/ckl082

[29] Baker, D. and Middleton, E. (2003) Cervical screening and health inequality in England in the 1990s. Journal of Epidemiology \& Community Health, 57, 417-423. doi:10.1136/jech.57.6.417 